6. Ignjatovic V, Pelkmans L, Kelchtermans H, Al Dieri R, Hemker C, Kremers R, et al. Differences in the mechanism of blood clot formation and nanostructure in infants and children compared with adults. Thromb Res. 2015;136:1303-9.

7. Yang J, Chen Y, Yu Z, Ding H, Ma Z. The influence of PM2.5 on lung injury and cytokines in mice. Exp Ther Med. 2019;18:2503-11.

8. Ng PC, Lam CW, Li AM, Wong CK, Cheng FW, Leung TF, et al. Inflammatory cytokine profile in children with severe acute respiratory syndrome. Pediatrics. 2004;113:e7-14.

9. Liniger M, Zuniga A, Tamin A, Azzouz-Morin TN, Knuchel M, Marty RR, et al. Induction of neutralising antibodies and cellular immune responses against SARS coronavirus by recombinant measles viruses. Vaccine. 2008;26:2164-74.

10. Prompetchara E, Ketloy C, Palaga T. Immune responses in COVID-19 and potential vaccines: Lessons learned from
SARS and MERS epidemic. Asian Pac J Allergy Immunol. 2020;38:1-9.

11. Ruf BR, Knuf M. The burden of seasonal and pandemic influenza in infants and children. Eur $\mathrm{J}$ Pediatr. 2014;173:265-76.

12. Benn CS, Netea MG, Selin LK, Aaby P. A small jab - A big effect: Nonspecific immunomodulation by vaccines. Trends Immunol. 2013;34:431-9.

13. Bureau IL. India Legal Bureau. Supreme court issues directions for prevention of children from Covid-19. 2020. Available from: https://www.indialegallive.com/ constitutional-law-news/supreme-court-news/supremecourt-issues-directions-prevention-children-covid-1994696. Accessed April 18, 2020.

14. Ella KM, Krishna Mohan V. Coronavirus vaccines: Light at the end of the tunnel. Available from: https:// www.indianpediatrics.net/CONVID29.03.2020/PERS00163. pdf. Accessed April 24, 2020.

\section{Does a Crying Child Enhance the Risk for COVID-19 Transmission?}

The pandemic of coronavirus disease (COVID-19) has led all of us to recalibrate both our personal and professional life [1]. In our routine pediatric outpatient practice for non-COVID cases i.e. well baby visits and kids presenting with afebrile, non-respiratory symptoms, a surgical face mask with proper hand hygiene and gloves has been recommended for health care professionals [2]. However, for those handling aerosol-generating procedures (AGP), respirators and additional personal protection equipment (PPE) are recommended [3]. Aerosol is defined as suspension of fine solid particles or liquid droplets in air or another gas. Aerosols of varying severity are generated on sneezing, coughing, talking and also during normal breathing [4]. AGPs are believed to produce aerosols and droplets as source of respiratory pathogens that exposes the health care workers to pathogens causing acute respiratory infections including Severe acute respiratory syndrome Coronavirus 2 (SARS-CoV-2) [5]. AGPs are generated on performing certain medical procedures like intubation, manual ventilation, non-invasive ventilation, tracheostomy insertion etc. on infected cases. However, it is not clear if the risk is due to direct airborne transmission or secondary exposure to respiratory droplets.

It is established that even loud speaking results in increased aerosol generation i.e. aerosol super-emission
[6]. Extrapolating the same logic even a crying and screaming child should produce aerosol super-emission. Although an operational definition for AGP is in place, the relation to crying and its possible effects of increased aerosol generation has so far not been stressed.

In a pandemic situation, we need to ponder on some points: even infants and toddlers who come for routine vaccinations or non-respiratory complaints can be asymptomatic carriers or in pre-symptomatic period of transmission; implementing source control measures like face mask and social distancing in this age group practically difficult; crying, a common occurrence in this age group, also increases the risk of aerosol generation and transmission; and, proximity of these kids to caregivers and their attenders along with sustained crying either due to anxiety or fear might further increase the risk and load of aerosol.

In view of the yet unknown increased risks posed by expected or unexpected crying of asymptomatic children in the transmission of COVID-19, it may be prudent to make every effort to avoid examining a crying child without adequate precautions.

Funding: None; Competing Interest: None stated. Published online: April 26, 2020; PII: S097475591600166

$$
\begin{array}{r}
\text { SoMU SIVABALAN }{ }^{1} \text { AND MV SRINATH }{ }^{2 *} \\
{ }^{1} \text { Department of Pediatrics, Kanchi Kamakoti CHILDS Trust } \\
\text { Hospital, } \\
\text { Nungambakkam, Chennai; and }{ }^{2} \text { Department of Pediatrics, } \\
\text { Saveetha Medical College and Hospital, Thandalam, } \\
\text { Kancheepuram; Tamil Nadu, India. } \\
* d r m v \text {mmc@yahoo.com }
\end{array}
$$




\section{REFERENCES}

1. Balasubramanian S, Rao NM, Goenka A, Roderick M, Ramanan AV. Coronavirus disease (covid-19) in childrenWhat we know so far and what we do not. Indian Pediatr. 2020 Apr 9. Available from: https://www. indianpediatrics.net/CONVID29. 03.2020/SA-00159.pdf. Accessed April 23, 2020.

2. Clinical Infectious Diseases Society, India. Infection control in stand-alone out patients and small nursing homes in the setting of COVID. Available from: http://www.cidsindia. org/pdf/covid-19/infection-control-in-standalone-OPs.pdf. Accessed April 25, 2020.

3. Ministry of Health and Family Welfare. Government of India. Novel Coronavirus Disease 2019 (COVID-19): Guidelines on rational use of Personal Protective Equipment. Available from: https://www.mohfw.gov.in/pdf/
GuidelinesonrationaluseofPersonalProtective Equipment. pdf. Assessed April 25, 2020

4. National Research Council. 2020. Rapid Expert Consultation on the Possibility of Bioaerosol Spread of SARS-CoV-2 for the COVID-19 Pandemic (April 1, 2020). Washington, DC: The National Academies Press. Available from: https:// www. nap.edu/read/25769/chapter/1. Accessed April 18, 2020.

5. Tran K., Cimon K., Severn M, Pessoa-Silva CL, Conly J. Aerosol generating procedures and risk of transmission of acute respiratory infections to healthcare workers: A systematic review. PLoS One. 2012; 7:e35797.

6. Asadi S, Wexler AS, Cappa CD, Barreda S, Bouvier NM, Ristenpart WD. Aerosol emission and superemission during human speech increase with voice loudness. Sci Rep. 2019; 9: 2348. Available from: https://www.nature.com/ articles/s41598-019-38808-z. Accessed April 18, 2020.

\section{The Imperative of Early Treatment for Children With COVID-19 Infection}

Acute respiratory syndrome coronavirus 2 (SARS-CoV-2) infection is uncommon in children [1], with greater morbidity and mortality in adults and elderly. Anumber of hypotheses may explain the low susceptibility of children to COVID-19 virus [2] viz, (i) immaturity and limited function of angiotensin-converting enzyme 2 (ACE2) receptors in children, as undifferentiated cells that express low levels of ACE2 are not readily infected by SARS-CoV; (ii) the immature innate immune system in young children results in less inflammation and consequently fewer symptoms; and, (iii) possible crossreactivity of antibodies against other viruses (influenza, adenovirus, respiratory syncytial virus etc.) with the SARS-CoV-2, which could provide partial protection.

As COVID-19 infection is not universally mild in children [3], it is important that they are protected as a vulnerable population, as still there is limited data on the risk factors for severe infection in children.

The long-term effects on the lungs of COVID-19 in children are not known, even for those with moderate symptoms. In patients hospitalized in French pediatric units in recent weeks, the chest computed tomography (CT) scans have often been pathological, even in children with limited respiratory sign with associated decline in lung function (unpublished data). In light of this, should not all children with moderate to severe respiratory symptoms be treated, irrespective of their comorbidity? Why do pediatricians appear to be unwilling to consider employing the COVID-19 treatments that are available, e.g., hydroxychloroquine and azithromycin [4]? These drugs (which are already widely used in pediatrics in other indications) certainly have side effects that are of concern, but their use in a hospital environment shall allow these side effects to be monitored and ensure greater safety for the patient [5].

In the absence of specific antiviral treatments, pediatricians need more virological, epidemiological, and clinical data to better treat and manage COVID-19 infections. It should be kept in mind that children, even when asymptomatic, may be a potential cause of spread and transmission of the disease in their communities [6]. In light of this, barrier precaution needs to be rigorously applied within families in order to protect the elderly.

Funding: None; Competing interest: None stated.

Published online: April 30, 2020; PII: S097475591600169

NARCisSe Elenga

Pediatric Medicine and Surgery,

Centre Hospitalier Andrée Rosemon, Rue des flamboyants, BP 6006, 97306, Cayenne Cedex, French Guiana. elengafr@yahoo.fr

\section{REFERENCES}

1 Dong Y, Mo X, Hu Y, Qi X, Jiang F, Jiang Z, et al. Epidemiological characteristics of 2143 pediatric patients with 2019 coronavirus disease in China. Pediatrics. 2020. Available from: https://pediatrics.aappublications.org/ content/pediatrics/early/2020/03/16/peds.2020-0702.full. $p d f$. Accessed April 24, 2020.

2. Li Y, Guo F, Cao Y, Li L, Guo Y. Insight into COVID 2019 